\title{
Investigating Language Learning Strategies Used By ESL Lower Secondary Learners from National and Vernacular School Background
}

\author{
Snehapraba Vimalakshan, Dr Azlina Abdul Aziz
}

\begin{abstract}
Learning English as a Second Language (ESL) in the context of English is indisputably complex. This requires several types of human cognition, and includes other variables, such as societal context and belief, social economic standing, motivation, and learning strategies itself. Basically, in Malaysia, learning English has been considered the second language and has been taught in both primary and secondary schools for years but there is still a big doubt regarding Malaysian ESL learners' skills. Several studies also shown that Malaysian ESL students are still displaying poor English abilities in addition to failing to master the expected language for certain purposes. This work is therefore mainly aimed to investigate the efficient language learning strategies that used by 60 secondary school learners from Klang in grasping the four major skills in English listening, speaking, reading, writing and vocabulary based on their various primary school background (sk/sjkt/sjkc). For that, a survey research design with a quantitative approach was employed whereby the data was gained from a set of questionnaires adapted from the inventory of Language Strategy Use which Cohen, Oxford and Chi (2005) developed. A total of 60 Form 1 students from diverse secondary schools in Klang district situated in Selangor were the respondents of this study. The results were analysed through descriptive statistics by calculating frequencies and percentages. The study revealed learners from different background use several language learning strategies in order to become an effective language learner. Therefore, teachers are suggested to analyse pupil's cultural background, belief, socioeconomic status, motivation and interest so that they can include innumerable learning strategies in their lesson plan.

Index Terms-: English as Second Language, Language Learning Strategies, Language Skills, Sekolah Kebangsaan, Sekolah Jenis Kebangsaan Tamil, Sekolah Jenis Kebangsaan Cina.
\end{abstract}

\section{INTRODUCTION}

Malaysia is a multicultural nation and three main ethnic groups, namely Malay, Chinese and Indian, constitute Malaysian learners. The students are introduced to the very first language or dialect depending on their ethnicity

Snehapraba Vimalakshan, National University of Malaysia, 43600, Bangi, Selangor, Malaysia

Dr Azlina Abdul Aziz, (Associate Professor Dr.) National University of Malaysia, 43600, Bangi, Selangor, Malaysia.
Their first languages could be Malay, Mandarin, or Tamil, or the family may choose their own preferred languages and cultures to communicate, including Chinese dialects, Tamil dialects, or any other native languages. However, when the pupils start their formal primary education, the schools educational medium relies on the types of schools: National or Vernacular type. The national type school uses Malay, while the vernacular schools use either Mandarin or Tamil as the instructional tool. The pupils learn English as an additional language subject. In other words, two languages are taught by pupils who attend the national school and three languages by those attending the vernacular schools. As a result, Malaysian pupils are either bilingual or multilingual. According to Thang et al.(2012) amid a period of years of formal English instruction, Malaysian pupils continue to be hampered by mainly due to individual differences such as personality, belief, motivation and the language learning strategies used in learning English. One of the most important factors which influence the acquisition of English language among the Malaysian ESL secondary school learners is differences in Language Learning Strategies used due to their various background of primary school education. Language Learning Strategies are the strategies used by means of learners to improve their language abilities such as listening, speaking, reading, writing, grammar and vocabulary. These techniques may be exceptional from one learner to another learner regardless of being in the same class and being taught with the aid of the same instructor in schools. Although language learning techniques vary from one individual to another, it can be identified and uncovered to several range of novices to help them to be successful language learners too. Therefore, this study aims to investigate the language learning strategies used by ESL secondary learners from national and vernacular school background, (sk, sjk (t) and SJK (C). With regards to the objective, this study aims to respond to the question: What are the language learning strategies used by ESL secondary pupils with various primary school background (SK, SJK (T) and SJK (C)? and Which strategy category is often used by the active students? 


\section{LITERATURE REVIEW}

\section{A. Language Learning Strategies}

Language Learning Strategies (LLS) are necessary for learners and teachers to consider developing students' language competency. Teachers tend to deal with a group of students in the classroom at one time, but language learning takes place differently in different individuals. For some students, therefore, one learning strategy works while the same learning strategy might not work for the other students. Teachers and learners have paid a great deal of attention not only to 'what to learn,' but also to 'how to learn.' To accomplish full language learning, the emphasis is usually on developing learning strategies which teachers should be aware of the variety of techniques involved in transmitting their English knowledge to learners. For instance, teachers can instruct the students well enough with good language learning strategies. The first step to understanding this strategy, however, is knowing what learning strategies are about.

Language learning strategies have been widely applied since the 1970 's. The studies were essentially based on factors such as learner skills, learning environment, race, age, gender, learning styles, motivation and belief which influence the learners learning strategies. One of the earlier researches was done by Rubin in 1975. He described strategies as "the techniques or tools, which a student may use to gain knowledge". He also defined "successful language learners" simply by looking at their strategies and performance in learning. Meanwhile, Rigney (1978) defined a learning strategy as "cognitive strategy" which is "used to signify operations and procedures that students can use to develop, retain and retrieve various types of information and performance." Later, Rubin (1981) did an investigation to find cognitive strategies in second language learning and became more acquainted with the differentiation between direct and indirect language learning procedures. In 1987, Rubin proposed language learning strategies as procedures which lead to the improvement of the language structure which the student constructs and shapes learning from that point onward. She likewise suggested that language learning strategies comprise of any arrangement of activities, steps, plans, schedules used by the student in getting, storing, recovering, and utilizing the information.

Besides that, Weinstein, Ridley, Dahl \& Weber (1989) explained that learning strategies are behaviours and thoughts that a learner engages in during learning and are intended to persuade the process of encoding the learner. Oxford and Crookall (1989) described language learning strategies as the learner's steps to assist in acquiring, storing, and retrieving information. They noted that techniques can be deliberately used, but with practice they can also become repetitive and automatic. According to Oxford (1996), LLS refers to the approaches used by learners to acquire new knowledge in order to turn it into a more efficient and fun experience, and those who use appropriate learning strategies are autonomous, innovative and dynamic. Adding to that, Scarcella \& Oxford (1992) described strategy as performing a series of tactics used to achieve some aim and learning strategy as a chain of learning-related to acts. Hall (2001) has the similar idea of learning strategies as goal-oriented actions that the learners used to mediate their own learning.Meanwhile, Cohen (2011) consented with Oxford's ideas that the objective of language learning strategies is to establish learning, perform with specific tasks, deal with various issues, make the learning process easier, faster, and more exciting, and offset a learning deficiency. The concept focuses more on learners' purpose and preference in using language learning strategies.

Oxford (1996) classified Language Learning Strategies (LLS) by six categories: memory, cognitive, compensation, metacognitive, affective, and social. Oxford (1996) stated that learners who often use the memory technique tend to learn by using imagery and grouping because this can enable them to remember details. At the other hand, learners who favour the cognitive approach like taking note of the knowledge they have got, practicing, and evaluating it. Meanwhile, learners who opt for the compensation strategy usually use strategies of conjecture and rephrasing to get to know the new information. Meta cognitive users, on the other hand, enjoy tasks such as self-monitoring, concentrating, and preparing for a task or project as these tasks allow them to recall, interpret and synthesize the information they have gained.The affective strategy refers to self-encouragement, as it consists of learners optimally managing their emotions and attitudes. Pupils using the social strategy enjoy communicating with their fellow classmates and interacting dynamically with others. According to Chang \& Liu (2013), Oxford's LLS classification is one of the most detailed system to date. This inventory has been extensively used to collect data for numerous studies around the world.

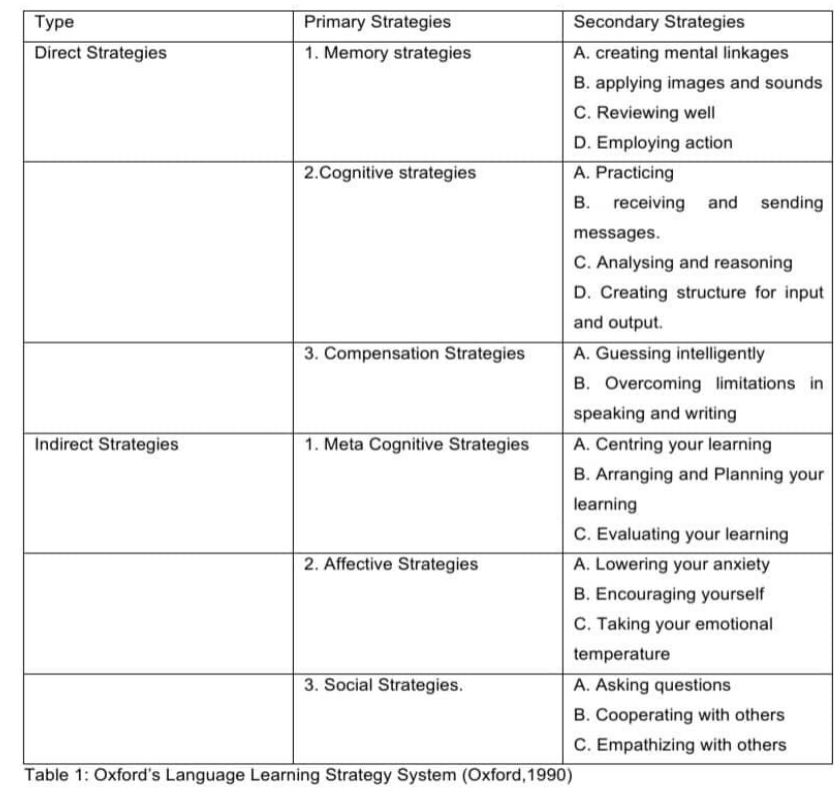




\section{METHODOLOGY}

\section{A. Research Design}

This study employed a survey research design with a quantitative approach. A quantitative research, according to Creswell (2017) is a type of research that explains phenomena by gathering numerical data which are analysed using mathematical methods. A questionnaire consisting statements related to language learning strategies based on four language skills which are listening, reading, writing and vocabulary speaking. The questionnaires were adapted from the inventory of Language Strategy Use which Cohen, Oxford and Chi (2005) developed. These questionnaires are constructed in a Google form and sent by the respective school teachers to the students to answer via Whats-app.

\section{B. Sampling}

The samples of this study were chosen based on random sampling looking into the student's availability. Moore and McCabe (1993) stated that random samples are acknowledged as the best evidence for decision-making and minimizing bias. This study involved 60 Form 1 students from three different secondary schools in Klang district. From the 60 form 1 students, 20 students are from the background of SK primary school, 20 students are from $\operatorname{SJK}(\mathrm{T})$ background and the other 20 students are from SJK (C) background. The reason why Form 1 students are selected for this study is because they are the latest intake to the secondary schools from SK, $\operatorname{SJK}(C)$ and $\mathrm{SJK}(\mathrm{T})$ primary schools in Klang. Adding on, specifically 20 students were chosen to get best evidence and accurate data.

\section{Instrument}

This research was conducted by administrating a questionnaire to randomly selected Form 1 secondary school students. The questionnaire adapted from the inventory developed by Cohen, Oxford and Chi (2005). Due to the proven reliability of this inventory in terms of validity there is no doubt. The questionnaire was divided into various language learning skills such as listening, speaking, reading, writing and vocabulary. The first skill listening contains 28 statements, speaking 18 statements, reading 12 statements, writing 10 statements and vocabulary 16 statements related language strategies used by the students. Students are required to select either always, sometimes or never in practising those strategies. The reliability of all questions in SILL questionnaire for all participants were very high and, in this study, the scale's Cronbach Alpha reliability coefficient was also found as $(\alpha=.89$ This shows that the scale can be used as an effective and consistent measurement instrument.

\section{Data Collection Procedure}

When conducting the studyan online survey consisting a set of questionnaires was sent through Google Forms in order to perceive student's preferred language learning strategies and all 60 students were given the same set of questionnaires. Due to the pandemic, it was carried out during the Movement
Control Order period so all the students were contacted through social network and was asked to complete the google doc. The survey in the google doc was evolved from the inventory that Cohen, Oxford and Chi (2005) developed. The survey was split into different learning areas including listening, speaking, reading, writing and vocabulary.

\section{E. Data Analysis}

Study results were analysed by percentage sumthrough Statistical Package for the Social Science (SPSS Ver.21). The research questions of this study were measured with descriptive statistics to identify students preferred language learning skills. The results of the analysis are presented

through the count of percentage and projected in table format. The table displays the percentage of respondents based on how accurate the statements characterise their ability-dependent experience of language learning methods as if it is desired or desired least. The table results were explained and discussed later on the language learning methods and attitudes of effective language learners.

\section{FINDINGS}

The findings of the research were discussed under four types of language skills which are listening, speaking, reading, writing and vocabulary. Discussion of strategies preferred the most and least are further discussed in the discussion section.Table 4.1: The most preferred strategy based on skills by SK background ESL secondary pupil.

\begin{tabular}{|l|l|l|l|l|}
\hline No & Skills & $\begin{array}{l}\text { Most Preferred } \\
\text { Strategy (Item) }\end{array}$ & Percentage & Strategy \\
\hline 1. & Listening & $\begin{array}{l}\text { I sometimes decide } \\
\text { to pay special } \\
\text { attention to specific } \\
\text { language aspects; for } \\
\text { example, the way } \\
\text { the speaker } \\
\text { pronounces certain } \\
\text { sounds. }\end{array}$ & $85 \%$ & $\begin{array}{l}\text { Metacognitive } \\
\text { strategy }\end{array}$ \\
\hline 2. & Speaking & $\begin{array}{l}\text { I regularly seek out } \\
\text { people with whom I } \\
\text { can speak English } \\
\text { language. }\end{array}$ & $75 \%$ & $\begin{array}{l}\text { Metacognitive } \\
\text { strategy }\end{array}$ \\
\hline 3. & Reading & $\begin{array}{l}\text { I make a real effort } \\
\text { to find reading } \\
\text { material that is at or } \\
\text { near my level. }\end{array}$ & $75 \%$ & $\begin{array}{l}\text { Metacognitive } \\
\text { strategy }\end{array}$ \\
\hline 4. & Writing & $\begin{array}{l}\text { I plan how I am } \\
\text { going to write an } \\
\text { essay, monitor to } \\
\text { see how my writing } \\
\text { is going, and then } \\
\text { check to see how } \\
\text { well I wrote what I } \\
\text { wanted to. } \\
\text { I often analyse } \\
\text { words to identify the } \\
\text { meaning of a part or } \\
\text { several parts of } \\
\text { them. }\end{array}$ & $75 \%$ & $\begin{array}{l}\text { Cognitive } \\
\text { strategy }\end{array}$ \\
strategy \\
\hline
\end{tabular}

Table 4.1: The most preferred strategy based on skills by SK background ESL secondary pupil 
Based on table 4.1, it can be concluded that the most preferred language learning strategy for SK background ESL secondary pupils is Metacognitive strategy. For listening $85 \%$ of the respondents agreed that they pay attention to the language aspects. For the speaking skill $75 \%$ of the respondents stated they regularly seek out people whom they can converse the language. Another $75 \%$ of respondents agreed they make effort to find a reading materials base on their proficiency level. As for writing nearly $70 \%$ of the respondents agreed that they arrange and plan their essay to evaluate their writing. Lastly, for vocabulary $75 \%$ of the respondents agreed that they analyse words to identify the meaning.

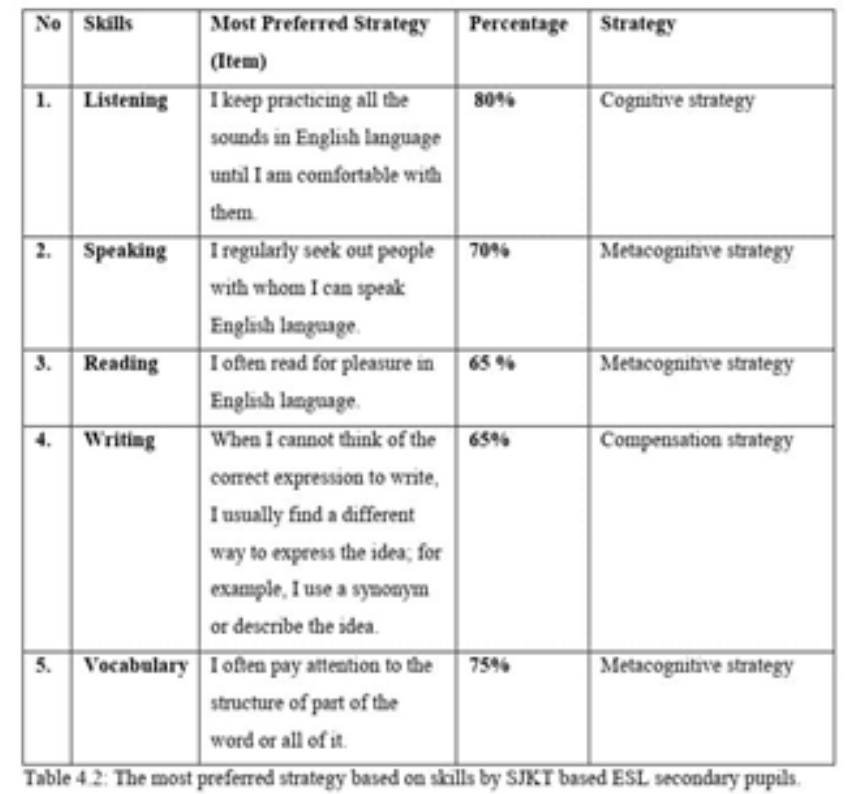

From the table 4.2, it can be concluded that the most preferred language learning strategy for SJKT background ESL secondary pupils is also Metacognitive strategy. They apply metacognitive strategy for speaking, reading and vocabulary. Around $75 \%$ respondents agreed that they always pay attention to the structure part of the word, $70 \%$ responded they regularly seek out people whom they can practice or converse the language and $65 \%$ agreed they often read for pleasure. On the other hand, $80 \%$ respondents use cognitive strategy to practice their listening skill and 65\% apply compensation strategy to overcome limitations in writing.

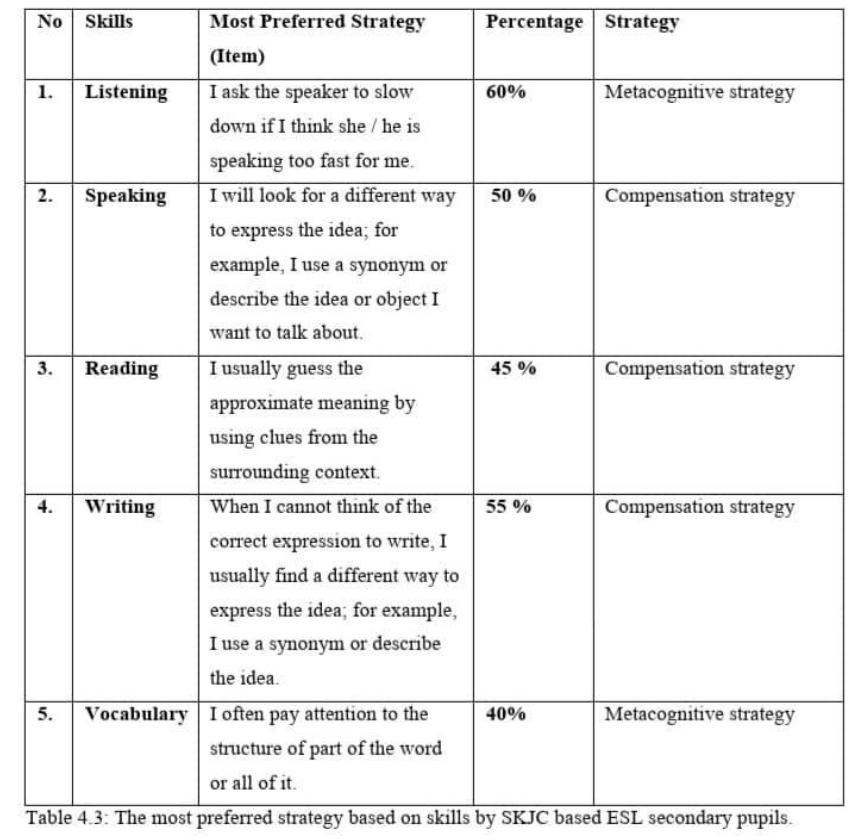

Based on table 4.3, it can be concluded that the most preferred strategy for SJKC based ESL secondary pupils is Compensation strategy. They apply compensation strategy for speaking, reading and writing. 55\% of the respondents agreed that they use synonyms to describe idea in writing, $50 \%$ agreed they will look for a synonym to describe their idea while speaking and lastly, they also use clues from the surrounding context to guess the approximate meaning when reading. On the other hand, for listening $60 \%$ agreed that they will ask the speaker to slow down if they think it's fast for them to catch up. For vocabulary $40 \%$ agreed that they use metacognitive strategy which is they often pay attention to the structure of part of the word.

As overall finding for the most preferred strategies, there are some similarities when it comes to SJKT and SJKC based ESL secondary pupils especially when it comes to the writing and vocabulary learning strategies where they tend to find a different way to express the idea for writing in English by using a synonym or describe the idea. They also seem to be paying more attention to the structure of part of the word or all of it. Meanwhile, the SK based ESL secondary pupils prefer to be more systematic when it comes to writing in English because they first plan on how to write an essay, monitor the process of their, and then check to see how well they have written as what they wanted or planned earlier. They also prefer to analyse words to identify the meaning of a part or several parts of the words when it comes to vocabulary. Therefore, it is obvious that the SK based ESL pupils are more organize and clear about the procedures of writing and usage of vocabulary compared to the SKJT and SJKC based ESL secondary pupils. Therefore, the secondary school teachers should be aware that a proper guide on the process of writing an essay is needed at secondary level as the students from the national type of pupils are noticeably struggling when it comes to drafting an essay. 


\begin{tabular}{|l|l|l|l|l|}
\hline No & Skills & Least Preferred Strategy (Item) & Percentage & Strategy \\
\hline 1. & Listening & $\begin{array}{l}\text { I listen for word and sentence stress to } \\
\text { see what English speakers emphasize } \\
\text { when they speak }\end{array}$ & $\mathbf{6 0 \%}$ & $\begin{array}{l}\text { Cognitive } \\
\text { strategy }\end{array}$ \\
\hline 2. & Speaking & $\begin{array}{l}\text { I often ask the person I'm talking with } \\
\text { to help me out. }\end{array}$ & $\mathbf{6 5 \%}$ & $\begin{array}{l}\text { Social } \\
\text { strategy }\end{array}$ \\
\hline 3. & Reading & $\begin{array}{l}\text { I usually make predictions as to what } \\
\text { will appear next in the text. }\end{array}$ & $\mathbf{6 0 \%}$ & $\begin{array}{l}\text { Compensation } \\
\text { strategy }\end{array}$ \\
\hline 4. & Writing & $\begin{array}{l}\text { I frequently take class notes in English } \\
\text { language. }\end{array}$ & $\mathbf{5 0 \%}$ & $\begin{array}{l}\text { Cognitive } \\
\text { strategy }\end{array}$ \\
\hline 5. & Vocabulary & $\begin{array}{l}\text { I sometimes use rhyming to remember } \\
\text { new words. }\end{array}$ & $\mathbf{6 5 \%} \%$ & $\begin{array}{l}\text { Memory } \\
\text { strategy }\end{array}$ \\
\hline
\end{tabular}

Based on table 4.4, we can summarize that the least preferred strategy based on skills by SK based ESL secondary pupils is Cognitive strategy. $50 \%$ of the respondents agreed that they never take notes for writing in English Language class where as $60 \%$ agreed that they listen for word and sentence stress to see what English speakers emphasize when they are speaking. On the other hand, memory and social strategies are also least preferred by respondents from SK.

\begin{tabular}{|c|c|c|c|c|}
\hline No & Skills & Least Preferred Strategy (Item) & Percentage & Strategy \\
\hline 1. & Listening & $\begin{array}{l}\text { I regularly attend out-of-class } \\
\text { events where the English language } \\
\text { is spoken. }\end{array}$ & $65 \%$ & $\begin{array}{l}\text { Cognitive } \\
\text { strategy }\end{array}$ \\
\hline 2. & Speaking & $\begin{array}{l}\text { I usually avoid topics I don't have } \\
\text { language for. }\end{array}$ & $75 \%$ & $\begin{array}{l}\text { Compensation } \\
\text { strategy }\end{array}$ \\
\hline 3. & Reading & $\begin{array}{l}\text { I make a real effort to find reading } \\
\text { material that is at or near my level. }\end{array}$ & $55 \%$ & $\begin{array}{l}\text { Cognitive } \\
\text { strategy }\end{array}$ \\
\hline 4. & Writing & $\begin{array}{l}\text { I usually look for ways to get } \\
\text { feedback from others, such as } \\
\text { having my peers put the text in his } \\
\text { I her own words, and then I } \\
\text { compare it to my original version. }\end{array}$ & $65 \%$ & $\begin{array}{l}\text { Social } \\
\text { strategy }\end{array}$ \\
\hline 5. & Vocabulary & $\begin{array}{l}\text { I may well practice new action } \\
\text { verbs by acting them out. }\end{array}$ & $75 \%$ & $\begin{array}{l}\text { Memory } \\
\text { strategy }\end{array}$ \\
\hline
\end{tabular}

Findings in the table 4.5 illustrated that the least preferred strategy based on skills by SJKT based ESL secondary pupils is also Cognitive strategy. $65 \%$ of the respondents agreed that they do not attend out of class events where the English language is spoken. As for reading skill, 55\% agreed that they don't make a real effort to find reading material based on their level. Meanwhile, for speaking 75\% agreed they don't avoid any topics that they don't have language for. Lastly, $65 \%$ of respondents stated they do not prefer feedbacks from their peers for their writing skill.

\begin{tabular}{|l|l|l|l|l|}
\hline No & Skills & Least Preferred Strategy (Item) & Percentage & Strategy \\
\hline 1. & Listening & $\begin{array}{l}\text { I usually draw on my general } \\
\text { background knowledge in an effort } \\
\text { to get the main idea. }\end{array}$ & $\mathbf{8 0 \%}$ & $\begin{array}{l}\text { Cognitive } \\
\text { strategy }\end{array}$ \\
\hline 2. & Speaking & $\begin{array}{l}\text { I may well say new expressions } \\
\text { repeatedly to myself in order to } \\
\text { practice them. }\end{array}$ & $\mathbf{8 0 \%}$ & $\begin{array}{l}\text { Cognitive } \\
\text { strategy }\end{array}$ \\
\hline 3. & Reading & $\begin{array}{l}\text { I make a real effort to find reading } \\
\text { material that is at or near my level. }\end{array}$ & $\mathbf{7 0 \%}$ & $\begin{array}{l}\text { Cognitive } \\
\text { strategy }\end{array}$ \\
\hline 4. & Writing & $\begin{array}{l}\text { I often try to write different kinds of } \\
\text { texts in English language (e.g., } \\
\text { personal notes, messages, letters, } \\
\text { and course papers). }\end{array}$ & $\mathbf{7 0 \%}$ & $\begin{array}{l}\text { Cognitive } \\
\text { strategy }\end{array}$ \\
\hline 5. & Vocabulary & $\begin{array}{l}\text { I sometimes visualize the spelling } \\
\text { of the new word in my mind. }\end{array}$ & $\mathbf{8 0 \%}$ & $\begin{array}{l}\text { Memory } \\
\text { strategy }\end{array}$ \\
\hline
\end{tabular}

From the table 4.6, we can summarize that the least preferred strategy based on skills by SJKC based ESL secondary pupils is also Cognitive strategy. $80 \%$ of respondents agreed that they do not draw general background knowledge in an effort to get the main idea while listening. For speaking skill $80 \%$ of respondents stated that they do not repeat any new expressions that they learnt in order to practice them. In addition, $70 \%$ respondents agreed that they do not make effort to write in various kind of texts in English language. For reading skill, $70 \%$ responded that they do not try to find any reading material near to their level. Lastly, for vocabulary $80 \%$ of respondents agreed that they do not visualize spelling of the new word in their mind. From the findings for the least preferred strategies, it is found that most of the ESL secondary pupils either from SK or SJKT or SJKC background do not prefer cognitive strategies. They mostly preferred metacognitive and compensation strategies. Cohen (2014), in his study found that successful learners widely used metacognitive strategies. But it is quite worrying to find out that most of the ESL secondary pupils are leastpreferred some of the good strategies for writing such as to write different kinds of texts in English language, take class notes in English language and look for ways to get feedback from others, such as having my peers put the text in his / her own words, and then compare it to their original version. These strategies can help the students to reduce their anciently when comes to writing essays during examination and at the same time it helps them to improve their writing skills. Therefore, teachers in secondary school should try to encourage students practice writing blogs and journals as students basically prefer to write for pleasure then academically.

\section{DISCUSSIONS}

Based on the survey conducted, it has been identified that the learners use various language learning strategies in order to become a successful language learner. Although different language learners preferred different language learning strategies, there are some strategies that are prominent among successful language learners. 
Among the three schools it can be concluded that ESL secondary pupils from SK and SJKT background mostly preferred metacognitive strategy. O’Malley et al. (1985) stated that metacognitive is an expression to indicate an executive function, strategies which involve planning for learning, thinking about the learning process as it is taking place, observing of one's production or comprehension, correcting your own mistakes, and evaluating learning after an activity is completed. Based on O'Malley's classification, advance organizers, directed attention, selective attention, self-monitoring, delayed production, and self-evaluation are included among the major metacognitive strategies. This strategy is clearly seen among the successful language learners in this study from SK and SJKT background. On the other hand, most preferable strategy among ESL secondary pupils from SJKC background is compensation strategy.Compensation strategies as language problem-solving techniques consist of various mental or physical activities carried out by students to resolve any language learning problems they encounter, and are divided into guessing intelligently and overcoming limitations in speaking and writing (Oxford,1996). SJKC background students apply compensation strategies to compensate for limitations in speaking and writing.

However, according to the survey cognitive strategy was the least preferred strategy among ESL secondary pupils from all three school. According to Brown (2007), cognitive strategies are more limited to specific learning tasks and they involve more direct manipulation of the learning material itself. These strategies refer to procedures and activities which learners apply to improve their ability to learn or remember the materials, and solve the problems, especially those actions which learners use with specific classroom tasks.

To sum up, to teach language learning strategies, educators have to analyse pupil's cultural background, belief, socioeconomic status, motivation and interest. Teachers should also include various learning strategies in their lesson plan. Successful language strategy training should be explicit, and learners are told exactly which behaviours are likely to be helpful. Blind training, where students are led to strategies without understanding is less successful.

\section{CONCLUSION AND RECOMMENDATION}

In short, we can draw a conclusion from this study that there have been numerous stated language learning strategies used by the students in order to acquire the language. It is significant that language teachers should be made aware of the strategies that are important for students' language learning, and thus students should be visible to various types of strategies that can be practically used in language learning. As suggested by Nguyen (2008), there is some basic principles that can be incorporated in teaching and learning strategies in order to boost student's acceptance in using the strategies. A few recommendations have been drawn based on that. Firstly, recreation of this study should be measured nationwide, with diverse age groups and bigger sample size. Secondly, casual relationship research is required so as to comprehend the relationship between the use of language learning strategies and the background variables affecting strategy use. Next, it is important to find out ESL teachers 'mindfulness and insight of language learning strategies. Only when these teachers are aware of and have knowledge of language learning strategies, they would be able to aid the students with the needed or specific strategies. Finally, teaching materials could advocate the use of strategies. This can be seen in Ellis and Sinclair 's (1989) book on aiding students to learn English.Henceforth, students should be able to see the reason and use the strategies efficiently to boost their aptitude in the language

\section{REFERENCES}

[1]Chamot, A. U. (2004). Issues in language learning strategy research and teaching. Electronic journal of foreign language teaching, 1(1), 14-26.

[2]Chang, C. H., \& Liu, H. J. (2013). Language Learning Strategy Use and Language Learning

Motivation of Taiwanese EFL University Students. Electronic Journal of Foreign Language Teaching, 10(2).

[3]Cohen, A. D. (2011). Second language learner strategies. Handbook of research in second Language teaching and learning, 2(Part V), 681-698.

[4]Cohen, A. D. (2014). Strategies in learning and using a second language. Routledge.

[5]Cohen, A. D., Oxford, R. L., \& Chi, J. C. (2005). Learning style survey for young learners: Assesing your own learning styles.

[6]Creswell, J. W., \& Creswell, J. D. (2017). Research design: Qualitative, quantitative, and mixed methods approaches. Sage publications.

[7]Dörnyei, Z. (2010). Researching motivation: From integrativeness to the ideal L2 self. Introducing applied linguistics: Concepts and skills, 3(5), 74-83.

[8]Ellis, G. and Sinclair, B. 1989. Learning to Learn English: a course in learner training.

[9]Hall, J. K. (2001). Classroom interaction and language learning. Ilha do DesterroA Journal of English Language, Literatures in English and Cultural Studies,

(41), 017-039.

[10] Hong-Nam, K., \& Leavell, A. G. (2006). Language learning strategy use of ESL students in an intensive English learning context. System, 34(3),

399-415.https://umpir.ump.edu.my/id/eprint/2068/1/A_comparison_o f languange learning strategies

adopted_by_secondary_and_university_students_in_Hong_Kong-Dr. Andrew_Tse- Journal-.PDF

[11] Khamkhien, A. (2010). Factors affecting language learning strategy reported usage by Thai and Vietnamese EFL learners. Electronic Journal of foreign Language teaching, 7(1), 66-85.

[12] Lai, Y. C. (2009). Language learning strategy use and English proficiency of university freshmen in Taiwan. TESOL quarterly, 43(2), 255-280.

[13] Maarof, Nooreiny, and Rohaya Yaacob. "Meaning-Making in the First and Second Language: Reading Strategies of Malaysian Students." Procedia - Social and Behavioral Sciences, Elsevier, 10 Mar. 2011, www.sciencedirect.com/science/article/pii/S1877042811001194.

[14] Min, H. T. (2006). The effects of trained peer review on EFL students' revision types and writing quality. Journal of second language writing, 15(2), 118-141. New York, Cambridge University Press.

[15] Moore, D. S., and McCabe, G. P. (1993), Introduction to the Practice of Statistics (2nd ed.), New York: W. H. Freeman.

[16] Nguyen, T.C.L. (2008). Learner autonomy and EFL proficiency: A Vietnamese perspective.

[17] Asian Journal of English Language Teaching, 18, 67-87 
[18] Olejarczuk, E. (2014). Investigating the relationship between learning styles, learning strategies and students' performance in a blended learning course: A research proposal. Konińskie Studia Językowe, 2(3), 257-271.

[19] O'Malley, J. M., Chamot, A. U., Stewner- Manzanares, G., Kupper, L., \& Russo, R. P. (1985). Learning strategies used by beginning and intermediate ESL students. Language learning, 35(1), 21-46.

[20] O'malley, J. M., O'Malley, M. J., Chamot, A. U., \& O'Malley, J. M. (1990). Learning strategies in second language acquisition. Cambridge university press.

[21] Oxford, R. L. (Ed.). (1996). Language learning strategies around the world: Cross-cultural perspectives (No. 13). Natl Foreign Lg Resource Ctr.

[22] Oxford, R., \&Crookall, D. (1989). Research on language learning strategies: Methods, findings, and instructional issues. The modern language Journal, 73(4), 404-419.

[23] Pintrich, P. R. (2003). A motivational science perspective on the role of student motivation in learning and teaching contexts. Journal of educational Psychology, 95(4), 667.

[24] Reid, J. M. (1995). Learning styles in the ESL/EFL classroom. Heinle\&Heinle Publishers, International Thomson Publishing Book Distribution Center, 7625 Empire Drive, Florence, KY 41042.

[25] Rigney, J. W. (1978). Learning strategies: A theoretical perspective. In Learning strategies (pp. 165-205). Academic Press.

[26] Rubin, J. (1975). What the" good language learner" can teach us. TESOL quarterly, 41-51.

[27] Rubin, J. (1981). Study of cognitive processes in second language learning1. Applied linguistics, 2(2), 117-131.

[28] Saad, N. S. M., Yunus, M. M., \&Embi, M. A. (2013). The Intersection between Out-of-Class Language Learning Strategies and In-Class Activities. Advances in Language and Literary Studies, 4(2), 132-140.

[29] Scarcella, R. C., \& Oxford, R. L. (1992). The tapestry of language learning: The individual in the communicative classroom.

[30] Stanley, G. (2006) Podcasting: audio on the internet comes of age. TESL-EJ 9 (4). Retrieved 15th June, 2006 from http://www-writing.berkeley.edu/TESL-EJ/ej36/int.pdf

[31] Takeuchi, O. (2003). What can we learn from good foreign language learners? A qualitative study in the Japanese foreign language context. System, 31(3)

385-392.

[32] Tam, K. C. H. (2013). A study on language learning strategies (LLSs) of university students in Hong Kong. Taiwan Journal of Linguistics, 11(2), 1-42.

[33] Teh K. S. M., Embi, M. A., Yusoff, N. M. R. N., \&Mahamod, Z. (2009). Language learning strategies and motivation among religious secondary school students. The International

[34] Journal of Language Society and Culture, 29(3), 71-79.

[35] Thang, S. M., Wong, F. F., Noor, N. M., Mustaffa, R., Mahmud, N., \& Ismail, K. (2012). Using a blended approach to teach English for academic purposes: Malaysian students' perceptions of redesigned course materials. International Journal of Pedagogies andLearning, 7(2), 142-153.

[36] Weinstein, C. E., Ridley, D. S., Dahl, T., \& Weber, E. S. (1989). Helping students develop strategies for effective learning. Educational Leadership, 46(4), 17-19.

[37] Weng, P. L. P. 2016, October 25. Successful Language Learning Strategies Used By Successful Year 5 English As A Second Language (Esl) Learners

[38] Yunus, Melor\&Sulaiman, Nur \& Amin, Mohammed. 2013. Malaysian Gifted Students' Use of English Language Learning Strategies. English Language Teaching. 6. 97-109. 10.5539/elt. v6n4p97.

SnehaprabaVimalakshan is an undergraduate who is pursuing her Masters of Education in TESL in National University of Malaysia, 43600 Bangi, Selangor, Malaysia. She graduated from Selangor University in 2013 with a Bachelor"s Degree in TESL. She is currently teaching English language in Pin Hwa High School, Klang, Selangor, Malaysia since 2013. She has participated in International Invention \& Innovative Competition (InIIC Series 2/2019) under Higher Institution Students (Social Science) category

Azlina Abdul Aziz is a TESL lecturer at the Faculty of Education, UKM.
She has a Masters degree in English Linguistics, minor in cross-cultural communication. Her Master's thesis examined the influence of culture in communication among a group of Malaysian Chinese students. She also has an Ed.D in Teaching of English from Teachers College, Columbia University, U.S.A. Her research interests are in the Teaching and Learning of Literature and Teacher Education in TESL. She is interested in how literary texts and personal narrative may be utilised to help students to examine the social, cultural and political issues in a particular context. She has been involved in organising drama workshops as well as personal narrative readings with her TESL undergraduate students. 